Postgrad. Med. J. (1965), 41, 48

Clinical Trial

\title{
BLIND TRIAL OF A DEGRADED CARRAGEENIN AND ALUMINIUM HYDROXIDE GEL IN THE TREATMENT OF PEPTIC ULCERATION
}

\author{
P. R. C. Evans, M.D., M.R.C.P. \\ S. NOWELL, F.F.R. \\ I. A. P. Thomas, F.F.R. \\ Wrexham Group of Hospitals
}

Much experimental work and a few clinical studies have been devoted to the anti-ulcer properties of sulphated polysaccharides (Babkin and Komarov, 1932; Schiffrin and Warren, 1942; Wolf and Wolff, 1943; Watt, 1959).

Ebimar (Evans Medical Ltd.) is such a substance derived from seaweed (Chondrus Crispus or Gigartina Stellata). Ebimar is based on carrageenan, a sulphated polygalactose. It is produced by depolymerising a crude extract of carrageenan, using phosphoric acid and hydrogen peroxide. This reduces the molecular weight of carrageenin from $100,000-700,000$ to about 20,000. By this process viscosity and gel formation are greatly reduced, making it easier to administer to patients. It is thought that ebimar consists largely of lambda-carrageenan and it has a sulphate content of $31 \%$ (Personal communication from Evans Medical Ltd.). Ebimar has been shown to combine with protein substrate and protects the substrate from peptic digestion. Gastric mucus, protein foods and the protein on an ulcer floor are acted upon in this manner (Anderson and Watt, 1959a, b, c; Bonfils, Dubrasquet and Lambling, 1959, 1960; Houck, Bhayana and Lee, 1960; Bonfils and Lambling, 1960a).

Watt and Marcus (in preparation), using a metachromatic stain, demonstrated that after oral administration of ebimar, prior to gastrectomy in humans, the substance was found in strands of mucus adherent to the gastric mucosa. Acid facilitates the formation of this complex, which has pepsin-inhibiting properties.

In uncontrolled clinical trials of ebimar, Bonfils and Lambling (1960b) treated 32 peptic ulcer patients who had failed to respond to other medicinal therapy. They were impressed with the results and so were Lambling, Bonfils, Kæss and Simonpoli (1960), who followed patients for up to 18 months. Both these papers emphasise the importance of dosage and the frequency of administration of the substance. Berthet (1961), Esposito (1962) and de Landazuri, Badell and Badell and Conchillo (1961) also reported favourably on ebimar. The latter advocate sucking the tablets. Esposito and Nicolini (1961) showed that in patients with a raised blood pepsinogen ebimar caused a return towards normal levels.
In 1959 we started a double blind trial of: ebimar and aluminium hydroxide gel in the $\underline{3}$. treatment of peptic ulceration.

\section{Method}

Patients with a radiologically proven gastric or duodenal ulcer, who agreed to join the trial, had + their names added to a list which determined at $\infty$ random what treatment they would receive. All 을 patients were rested for the first four weeks andwere advised to keep to a generous dyspepsia diet throughout the trial. They were seen at the outpatient clinic weekly for the first month and then once a month. Patients with gastric ulceration had mothly barium meal X-ray examinations until healing was complete, whilst those with duodenal ulcere- $\vec{\varphi}$ tion were re-X-rayed approximately every thre o months. Whenever possible repeat X-ray examin tions were undertaken by the same radiologist.

The patients were given either ebimar $1 \mathrm{~g}$. Or aluminium hydroxide gel $0.7 \mathrm{~g}$. tablets, to be chewed and swallowed half way between each meal and three times this dose last thing at night. Every three months the treatment was switched. The $\unrhd$ two preparations were known by a code number $\vec{F}$ and the clinician and radiologists were unaware which treatment the patients were receiving until after the final analysis of the results.

Clinical assessment at each interview was made as follows :

Grade A-no pain or other symptoms
Grade B-minor pain and/or occasional vomiting Grade C-severe pain and/or frequent vomiting.

\section{Material}

The series consisted of 11 females and 24 males with duodenal ulceration (average age 40 years, range 16-65) and five patients with gastric ulceration 윽 (two females and three males, age 27-72 years).

\section{Results}

There was no difference in the average weight increase in the two groups. One patient on ebimar o complained of mild diarrhœa and 3 complained $N$ of constipation. Amongst those on aluminium $N$ hydroxide 6 complained of constipation, one of $\omega$ whom became so constipated that he had to be? switched to ebimar.

Fig. 1 gives the periodical clinical assessment $\frac{\overparen{D}}{\mathscr{}}$ for the series. During the period one patient $\stackrel{\mathcal{P}}{+}$ treated with ebimar was referred for surgery 0 because of continuing pain and vomiting after $\bar{O}$ two months (included in Fig. 1 as having severe pain). 


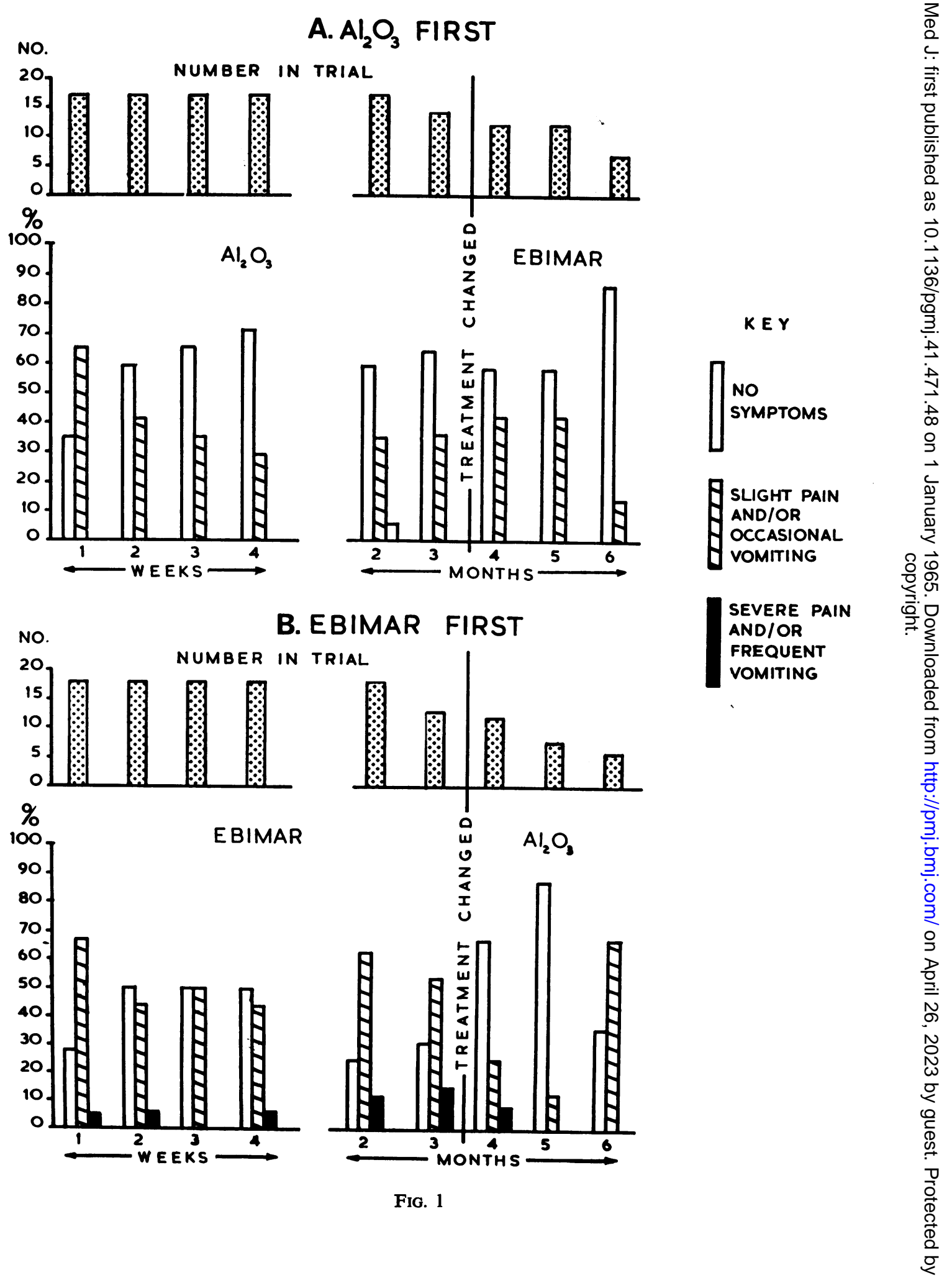


Fig. 1 suggests that initial treatment with aluminium hydroxide gave better results than initial treatment with ebimar: but later treatment with ebimar may have had a small advantage. This latter view is slightly supported by the few follow-up interviews at 7, 8, 9 and 10 months, as during this period 8 interviews of patients on ebimar recorded that the patients were symptomfree. Those on aluminium hydroxide reported at 10 interviews that they had been symptom-free during the last month, but there were 5 interviews when minor pain and/or occasional vomiting was noted, no definite conclusions can be reached, however, because of the small numbers.

The 5 patients with gastric ulceration were all symptom-free and radiologically healed by the 3rd month, irrespective of which treatment they had received.

If radiology at the initial examination of a patient with duodenal ulceration showed a definite ulcer crater, subsequent barium meals showed that there was a preponderance of nonhealing ulcers with either treatment. No significant difference between the healing properties of ebimar and aluminium hydroxide was found.

In view of these indecisive findings (which were not analysed statistically, as the numbers were so small), the beneficial effects of ebimar in some cases and the importance given in the literature to dosage and method of administration, it was decided to undertake a second trial amongst new consenting patients.

\section{Method}

The original diet was used and again the clinician and radiologists were unaware which treatment the patients were receiving. Tablets of ebimar $0.5 \mathrm{~g}$. and aluminium hydroxide gel $0.7 \mathrm{~g}$. were used. The patients were told to place a tablet between the upper gum and cheek and allow it to dissolve slowly (if possible without chewing) at the following times: on waking, 1 hour after breakfast, 1 hour before and 1 hour after the mid-day meal, 1 hour before and 1 hour after the evening meal and also prior to retiring for the night. They were advised to take an extra tablet after alcohol and were encouraged to spend the first 2 weeks away from work, resting as much as possible. All patients were seen at the clinic every 2 weeks for the first month and subsequently once a month. The radiological arrangements were the same as in the first trial.

In this trial the analysis of results was undertaken by an independent statistician who used a different method of clinical assessment. The data from the original case records were abstracted, tabulated, transferred to cards and analysed statistically. Until all calculations were completed only the code numbers of the two treatments were known to those working out the results. Scores of 0 to 4 were given for the severity and also for the frequency of pain, absence of pain scoring 0 and very severe or very frequent pain scoring 4 . The scores for each patient in each group was divided by twice the number of patients in that group.

\section{Material}

Assessments could be made from the records of 26 patients who had received aluminium hydroxide 0 continuously and from 27 patients who had taken. ebimar continuously. All these patients had radio- $\Rightarrow$ logical evidence of an active ulcer at the start of the trial. Table 1 shows that the patients receivingo the two treatments were reasonably matched for $\frac{C}{0}$ diagnosis, age and sex.

The patients on ebimar were followed up for $\frac{\bar{p}}{7}$ an average of 9.6 months (2-18 months) and those ${ }^{\Phi}$ on aluminium hydroxide for an average of 9.8 months (1-18 months). Patients who had a hiatalos hernia were not included in the trial. Surgery was $\vec{\circ}$ resorted to (after 1 month) on 1 patient with a.duodenal ulcer taking aluminium hydroxide and $\overrightarrow{\vec{\omega}}$ (after 14 months) on 1 patient with a gastric ulcer taking ebimar.

\section{Results}

Pain. Table 2 gives the patients' own reports about pain before and at the end of the trial. It shows that 7 patients receiving ebimar still had frequent or severe pain at the last assessment, $\infty$ whilst the figure for aluminium hydroxide was 2 .을 Fourteen patients on ebimar and 17 on aluminium hydroxide had no pain at the final interview.

The mean score at the beginning ior those on ebimar was 4.43 and for those on aluminium hydroxide 4.22 , the final scores for the whole period being 2.11 and 1.11 respectively. Thgs $\overrightarrow{0}$ reduction was significant at the level of $P<0 . \$$ for both types of treatment but the differenge between the two throughout the period of obset vation was not significant $(\mathrm{t}=1.68, \mathrm{P} \bumpeq 0.1)$.

Weight changes were similar in the two groups.

Bowel habits. No melæna was recorded in $\stackrel{\odot}{\varnothing}$ either group, and 1 patient in each group com- $\overrightarrow{\vec{P}}$ plained of diarrhœa. 5 patients on ebimar had $\frac{3}{3}$ constipation and 13 on aluminium hydroxide. This difference was statistically significant (Gran Chi, or $x^{2}=5.12, P \bumpeq 0.02$ ).

Radiological changes. Barium meal X-ray examinations were performed at rather irregular intervals, owing to pressure of work on the 3 . Department; the division of the trial into 5-month periods is somewhat arbitrary, but it is the most logical one that can be made.

The difference between those with no ulcer 을 seen after 5 months, calculated by a $2 \times 2$ chi $\frac{7}{O}$ squared table with a correction for continuity, was statistically just significant in favour of $N$ aluminium hydroxide $\left(x^{2}=4.06, P<0.05\right)$. The results at the end of the trial showed no difference, $\mathbb{N}$ as far as complete healing was concerned, స్ట between the two groups $\left(x^{2}=1.53, P>0.10\right)$. 0 If those are included who were radiologically improved at the end of the experiment, $80 \% \frac{0}{0}$ benefited from ebimar and $68 \%$ from aluminium hydroxide, but these differences were again not ${ }^{+}$ significant. The conclusion therefore is that there $\frac{0}{0}$ was some radiological evidence in favour of $\frac{\vec{D}}{\mathbb{D}}$

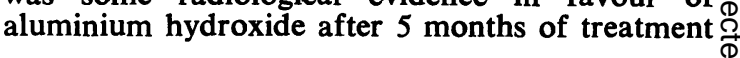


TABLE 1

DiAGNOSIS, AGE AND SEX OF THE PATIENTS ON EACH TREATMENT

\begin{tabular}{|c|c|c|c|c|c|c|}
\hline Tablet & Sex & Age & Duodenal & $\begin{array}{c}\text { Type of Ulcer } \\
\text { Gastric }\end{array}$ & Both & Total \\
\hline \multirow{3}{*}{$\mathrm{Al}_{2} \mathrm{O}_{3}$} & Male & $\begin{array}{c}\text { Under } 30 \\
30-50 \\
\text { Over } 50 \\
\text { Total }\end{array}$ & $\begin{array}{r}9 \\
6 \\
2 \\
17\end{array}$ & 0 & $\begin{array}{l}1 \\
1\end{array}$ & $\begin{array}{r}9 \\
6 \\
3 \\
18\end{array}$ \\
\hline & Female & $\begin{array}{c}\text { Under } 30 \\
30-50 \\
\text { Over } 50 \\
\text { Total }\end{array}$ & $\begin{array}{l}4 \\
1 \\
5\end{array}$ & $\begin{array}{l}1 \\
1 \\
1 \\
3\end{array}$ & 0 & $\begin{array}{l}1 \\
5 \\
2 \\
8\end{array}$ \\
\hline & Total & & 22 & 3 & 1 & 26 \\
\hline \multirow{3}{*}{ Ebimar } & Male & $\begin{array}{c}\text { Under } 30 \\
30-50 \\
\text { Over } 50 \\
\text { Total }\end{array}$ & $\begin{array}{r}7 \\
11 \\
2 \\
20\end{array}$ & $\begin{array}{l}1 \\
1 \\
2\end{array}$ & 0 & $\begin{array}{r}8 \\
12 \\
2 \\
22\end{array}$ \\
\hline & Female & $\begin{array}{c}\text { Under } 30 \\
30-50 \\
\text { Over } 50 \\
\text { Total }\end{array}$ & $\begin{array}{l}3 \\
3\end{array}$ & $\begin{array}{l}1 \\
1\end{array}$ & $\begin{array}{l}1 \\
1\end{array}$ & $\begin{array}{l}0 \\
3 \\
2 \\
5\end{array}$ \\
\hline & Total & & 23 & 3 & 1 & 27 \\
\hline
\end{tabular}

TABLE 2

\begin{tabular}{|c|c|c|c|c|}
\hline & NUMBER OF & PATIENTS REF & RTING PAIN & \\
\hline & $\begin{array}{l}\text { Very severe } \\
\text { or continuous }\end{array}$ & $\begin{array}{l}\text { Severe or } \\
\text { frequent }\end{array}$ & $\begin{array}{l}\text { Moderate and } \\
\text { not frequent }\end{array}$ & No pain \\
\hline $\begin{array}{c}\text { Ebimar } \\
\mathbf{A l}_{2} \mathrm{O}_{\mathbf{2}}\end{array}$ & $\begin{array}{cc}\text { Before } & \text { After } \\
1 & 0 \\
2 & 0\end{array}$ & $\begin{array}{cc}\text { Before } & \text { After } \\
8 & 7 \\
11 & 2\end{array}$ & $\begin{array}{cc}\text { Before } & \text { After } \\
17 & 6 \\
12 & 7\end{array}$ & $\begin{array}{cc}\text { Before } & \text { After } \\
1 & 14 \\
1 & 17\end{array}$ \\
\hline
\end{tabular}

TABLE 3

SUMMARY OF RESULTS WITH BARIUM MEALS

Ebimar (20 patients)

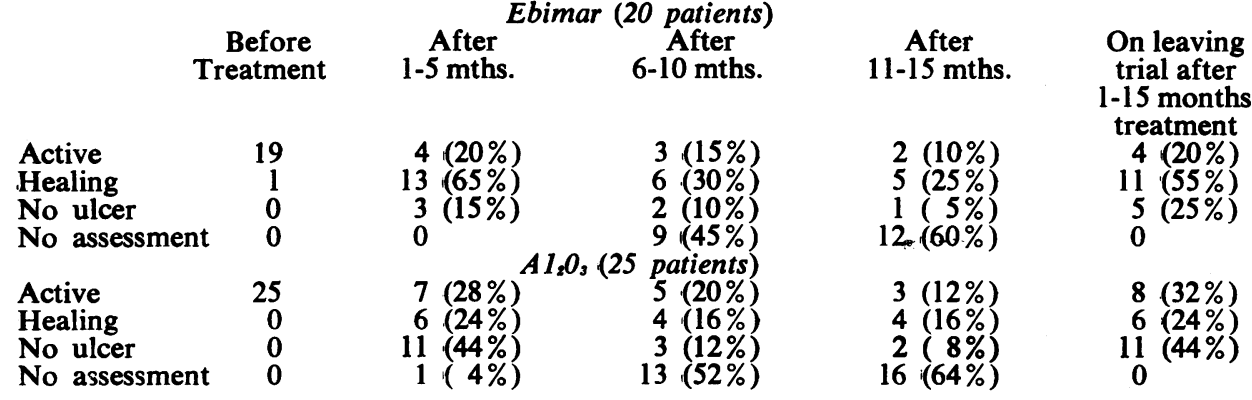

TABLE 4

1. Free of all symptoms

2. Some mild symptoms remain, but no loss of weight, no vomiting; barium meal shows no ulcer

3. All findings improved and no vomiting, no severe pain, but some weight loss or radiological evidence of ulcers remain

4. Some findings improved and none worse

5. No significant improvement

$\begin{aligned} \begin{array}{c}\mathrm{Al}_{2} \mathrm{O}_{3} \\ 4(15 \%)\end{array} & \begin{array}{l}\text { Ebimar } \\ 5(15 \%)\end{array} \\ 3(12 \%) & 0 \\ 5(19 \%) & 7(26 \%) \\ 11(42 \%) & 8(30 \%) \\ 3(12 \%) & 8(30 \%)\end{aligned}$


but none at the end of the follow-up period.

General assessment of treatment. The patients were graded into 5 groups at the end of their treatment, taking into account all recorded symptoms, including vomiting and melæna.

Three patients showed no improvement after aluminium hydroxide and neither did 8 after ebimar, but this difference was not significant. $\left(\mathrm{X}^{2} 2.45, \mathrm{P}>0.10\right)$. If it is assumed that from the patient's point of view the treatment was effective only in the first three groups in Table 4, there was no difference between the two groups, $46 \%$ improving on aluminium hydroxide and $41 \%$ on ebimar.

\section{Comment}

The results clearly show that many patients with peptic ulceration obtain relief from symptoms and avoid surgery (for some time at least), if treated as out-patients with rest, diet and an antacid or an antipeptic drug. It is not possible however, on the above findings, to conclude that one treatment is more effective than the other. There is no evidence from these trials to suggest that a larger number of patients or a different dosage schedule for either drug might show a clear-cut advantage of one drug over the other. It is, however, possible that a combination of the two drugs (aluminium hydroxide after meals and ebimar an hour or two later) might show an advantage over one or the other drug given alone. Marquez and Garcia (1960) as a result of in vitro experiments advises against using a combined tablet.

Two definite points emerge. First, ebimar causes less constipation than aluminium hydroxide; this view is strengthened by the fact that on their diet sheets all patients were advised to take liquid paraffin or milk of magnesia if they became constipated, so that if laxatives had not been used more patients might have reported constipation after aluminium hydroxide. The second point is that patients preferred ebimar (either chewed and swallowed or kept between cheek and gum) to aluminium hydroxide gel. Many patients with dentures complained that particles of the latter got under their plates and caused discomfort.

\section{Summary}

In two blind trials of degraded carrageenin (Ebimar) and aluminium hydroxide gel in the treatment of peptic ulceration, using different dose schedules in the two trials, degraded carrageenin and aluminium hydroxide both appeared to be effective in giving symptomatic relief but neither seemed to influence the natural history of the diseases.

We express our thanks to Evans Medical Ltd., for providing us with the drugs and to their medical and scientific staff for their help. Our thanks go also to the Sisters in the out-patient department of the War Memorial Hospital, Wrexham, and Mrs. Jones and Mrs. Parry for secretarial assistance.

\section{REFERENCES}

Anderson, W., and Watt, J. (1959a): The Protective Action of an Algal Polyanion against Experimen-@ tally Produced Peptic Ulceration in the Guinea Pig,.. J. Physiol., 147, 52P.

ANDERSON, W., and WATT, J. (1959b): Inhibition of Peptic Activity, Protection against Histamineo Ulceration in the Guinea Pig, and Combination with Gastric Mucin by an Algal Polyanion, J. $\frac{\text { क }}{\frac{5}{7}}$
Pharm. (Lond.), 11, 318.

ANDERSON, W., and WATT, J. (1959c): The Compara- $-\mathbb{Q}$ tive Protective Effects of Degraded Carrageenin and Aluminium Hydroxide on Experimentallyes Produced Peptic Ulceration, J. Pharm. (Lond.), 11, $\vec{\circ}$ 173T.

BabKin, B. P., and Komarov, S. A. (1932): The $\overrightarrow{-}$ Influence of Gastric Mucus on Peptic Digestion, $\omega$ Canad. med. Ass. J., 27, 463.

BerTHET, G. (1961):" Résultats de Dixhuit Moiso을 d'Experimentation d'un Antipeptique (Ebimar) dans 3 les Ulcères Duodenaux, Gazz. méd. Fr., 68, 2789.

Bonfils, S., DubrasqueT, M., and Lambling, A.(1959): Modifications Secrétoires Gastriques après Introduction, dans la Cavité Stomacale, d'unInhibiteur de la Protéolyse Peptique (Polysac- $\vec{\infty}$ charide C16), Med. Exp. (Basel), 1, 239.

BonfILS, S., DUbrasqueT, M., and LAMBling, A. (1960): L'Inhibition de la Protéolyse Peptique par Divers Polysaccharides, Rev. franç. Etudes clin. ָे biol., 5, 71 .

Bonfils, S., and Lambling, A. (1960a): Etudes Biologiques et Experimentales sur un Polysac charide Inhibiteur de la Protéolyse Peptique, $\overrightarrow{\mathcal{Q}}$ Commun. Soc. suisse allem. gastroenterol. (Zuğ, Sept.

Bonfils, S., and Lambling, A. (1960b): Activedít Thérapeutique d'un Inhibiteur de la Protéolys Peptique Polysaccharide (Cl6) Etudes sur la Doleur et l'Image Radiologique de l'Ulcère Gastroduo-ō denal, Thérapie, 15, 612.

EsPosITO, S. (1962): Risultati Ottenuti nella Terapia $\frac{\mathscr{Q}}{\varnothing}$ della Malattia Ulcerosa con il Polisaccaride C16, 응 Riv. Gastro-ent., 39, 196.

Esposito, S., and NicolinI, E. (1961): Ricerche sull'azione di un Polisaccaride Solfato sulla Secrezione Peptica della Mucosa Gastrica, Gazz. med. ital., $120,485$.

Houck, J. C., Bhayana, J., and Lee, T. (1960): The Inhibition of Pepsin and Peptic Ulcers, Gastroenterology, 39, 196.

Lambling, A., Bonfils, S., Kaess, H., and SimONPOLI, Ch. (1960): Etudes Preliminaires de l'Action d'un Polysaccharide Inhibiteur de la Protéolyse Peptique $O$ sur l'Ulcère Gastroduodenal, Commun. Soc. suisse

allem. gastroenterol. (Zur.), Sept.
MARQUEZ, V. M., and GARCIA, G. R. (1960): Carra- ำ geenan, a Contribution to the Study of its Mode $\frac{D}{0}$ of Action, Rev. Fac. Farm. Esp., 3, 196.

OrTiz de Landazuri, E., Badell, M., and Conchillo, F. (1961): Tratamiento del Ulcus Gastrodudenal o con Polisacaridos Sulfatados, Rev. Med. Est. gen. N Navarra., 5, 59.

SCHIFFrIN, M. J., and WARREN, A. A. (1942): Some $N^{-}$ Factors Concerned in the Production of Experimental Ulceration of G-I Tract in Cats, Amer. J. dig. Dis., 9, 205.

WATr, J., (1959): The Mechanism of Histamine Ulceration in the Guinea Pig, Gastroenterology, 37, 741 .

Wolf, S. and WolfF, H. G. (1943): The Gastric Mucosa 'Gastritis' and Ulcer, in Human Gastric $\mathbb{\Phi}$ Function, London: Oxford University Press. 